\title{
Short QTc Interval
}

National Cancer Institute

\section{Source}

National Cancer Institute. Short QTC Interval. NCI Thesaurus. Code C102709.

An electrocardiographic finding of a QT interval corrected for heart rate that is shorter than the lower limit of normal. Thresholds for different age, gender, and patient populations exist. (CDISC) 